This is a self-archived version of an original article. This version may differ from the original in pagination and typographic details.

Author(s): Tyrväinen, Olli; Karjaluoto, Heikki

Title: A Systematic Literature Review and Analysis of Mobile Retailing Adoption

Year: 2019

Version: Accepted version (Final draft)

Copyright: (c) 2019 Taylor \& Francis Group, LLC.

Rights: In Copyright

Rights url: http://rightsstatements.org/page/lnC/1.0/?language=en

Please cite the original version:

Tyrväinen, O., \& Karjaluoto, H. (2019). A Systematic Literature Review and Analysis of Mobile Retailing Adoption. Journal of Internet Commerce, 18(2), 221-247.

https://doi.org/10.1080/15332861.2019.1595364 


\title{
A Systematic Literature Review and Analysis of Mobile Retailing Adoption
}

\begin{abstract}
The purpose of this study is to provide a comprehensive updated review and analysis of mobile retailing adoption. Although research on mobile channel utilization has increased significantly in recent years and many new studies on this topic have been published, research has not yet provided a clear structure regarding how consumers' expectations have advanced in relation to mobile retailing adoption. Thus, this study synthetizes the mobile retail adoption literature and develops a framework for it. Our systematic literature review analyzed 94 scientific articles that were published between 2010 and 2018 to determine customers' different expectations and demands during different mobile channel adoption stages. Our findings enhance the understanding of how retailers can serve customers in each stage. In addition, our framework provides opportunities and provokes questions for further research as well as shifts the focus from technology adoption-oriented topics toward customer journeys.
\end{abstract}

Keywords: mobile shopping, smartphones, retailing, review article

\section{Highlights:}

- Customers' previous mobile shopping experience, their stage of mobile channel use, and the retailing context determine which features are the most valuable.

- In the initial stages of use, when customers are unfamiliar with mobile technologies and thus lack experience on mobile channels, they prefer utilitarian benefits.

- In later stages, when customers are familiar with mobile channels, they value more hedonic aspects.

- A mobile channel is not seen as a purchasing channel but rather as a searching channel. If retailers succeed in turning a mobile channel into a purchasing channel, they can provide deeper and more satisfying customer experiences. 


\section{Introduction}

In 2017 web traffic from mobile devices peaked above traffic from computers (Qubit 2018).

Consequently, retailers must now react to this evolution and do business on the digital field. Today, customers' experiences depend on mobile channels as well as physical environments and web stores. Physical and virtual channels are interconnected, which makes serving consumers more complicated (Carvalho and Campomar, 2014). These channels should provide a seamless retail experience because both influence the retail customer experience, and each touchpoint influences both brand and retail performance (Verhoef et al., 2015). Thus, the in-store experience should be redefined as part of a larger and more connected customer experience (Blázquez, 2014).

Consumers are increasingly spending more time on smartphones relative to other devices (Sing and Swait, 2017). They are using retailers' online channels on their mobile devices via applications that provide integrated information for customers (Oh et al., 2012). By 2016, 81 of the 100 biggest retailers in the U.S. had their own mobile apps, which they can use to provide a better customer experience than mobile websites because functions and interfaces perform better in applications (Koo, 2016). While traditional retailing is based on a model in which consumers enter the retail environment, mobile channels are changing that by allowing retailers to enter a consumer's environment both anywhere and at any time, which eliminates dependency on a store's location (Shankar et al., 2010).

Mobile retail applications do not require large monetary investments (Pantano, 2014); rather, they are often developed as an add-on feature to already existing channels, which can limit a customer's shopping experience (Cook, 2014; Bang et al., 2013b). However, every channel should be similar in certain areas, such as price, product data, and promotions (Cook, 2014). In addition, perceived differences between mobile and online channel technologies and value can significantly affect a consumer's transfer between online and mobile channels. If a mobile channel has greater speed, consumers are more willing to choose it versus an online channel (Cao and $\mathrm{Lu}, 2015)$. Mobile applications also allow retailers to 
utilize biometric technologies, such as fingerprint readers, to identify and profile potential customers through their mobile activities (Hino, 2015). Profiling allows retailers to personalize their marketing content, which strengthens customers' satisfaction (Trivedi and Trivedi, 2018).

The information searching process via mobile devices differs from computer searches because mobile screens are smaller, and consumers are reading content intermittently (Goh et al., 2015). Notably, smaller screen sizes may increase search costs (Chau et al. 2018). Consumers typically conduct searches on mobile devices, yet they tend to make purchases in physical stores (Sing and Swait, 2017). In addition, they often use their mobile devices in the store to compare prices online prior to making an in-store purchase (Piotrowicz and Cuthbertson, 2014). Wang et al. (2015) found that consumers tend to rely on previous choices when mobile shopping because screen size and functionality are limited. In addition, perceived quality of a retailer's e-service facilitates the belief that a mobile channel provides high-quality service (Lin, 2012).

Our research motivation derives from remarks that the mobile retailing field has developed rapidly since the conduction of previous literature reviews. Notably, there is no clear structure regarding how consumers' expectations have advanced in their journey toward mobile retailing adoption. Therefore, our research provides a deep analysis of past mobile retailing literature, with a specific focus on what have we learned from mobile retail adoption research.

In addition, no studies have presented a comprehensive review and analysis of mobile retailing adoption in recent years. Our article builds on and complements related research in important ways. Ström et al. (2014) noted a lack of studies about the value of mobile shopping for consumers. However, after 2014, several articles were published on that topic. The objective of this article is to synthetize the mobile retail adoption literature, develop a framework for it, and finally offer suggestions for future research opportunities.

The remainder of the article is organized as follows. We firstly present the utilized methodology of this systematic literature review and follow with the study's results. The main studies from both 
hedonic and utilitarian views are presented in Tables 4 and 5. We conclude with theoretical contributions, managerial implications, and suggestions for future research directions.

\section{Method}

This study followed the systematic literature review model of Palmatier et al. (2017). During the topic formulation step, objectives and research questions for the review were set. Next, procedures and methods for evaluation of published works were developed. The main studies on the topic were analyzed, and relevant keywords for constructing search strings were identified. The objective was to define explicit criteria that could be used in the review. The search strings are presented in Table 1, and the inclusion/exclusion criteria are presented in Table 2.

Table 1 Search strings

\begin{tabular}{ll}
\hline Theme & Search String \\
\hline Retailing & retail* OR shopping \\
Mobile & mobile OR smartphone \\
Adoption aspects & hedonic OR utilitarian
\end{tabular}

\subsection{Searching and screening}

The main objective of this review was to identify articles that had addressed mobile retailing adoption, including recent reviews of the mobile commerce (m-commerce) literature (Groß, 2015b; Ström et al., 2014; Thus et al., 2007). The reviewed articles were extracted from many different scientific peerreviewed journals (Table 3). The aim of this step was to locate all relevant studies for this research (Palmatier et al., 2017). The examination began with a detailed search of previous reviews. Three electronic databases - Elsevier, Taylor and Francis, and Emerald Insight—were searched for articles whose titles, keywords, or abstracts contained at least one of the search terms from the retailing and mobile themes. In addition, full texts were searched for the adoption aspect theme. This search returned 212 articles.

The next task was determining which studies met the eligibility requirements (Palmatier et al., 2017). A preliminary screening of article titles and abstracts led to the retention of 61 articles that were 
relevant to the topic. In addition, 20 articles from ResearchGate, 14 other articles, and 2 conference papers, which might not have been accessible in the online databases, were added from the authors' prior reading and the snowballing of database-sourced articles. These 97 articles were scored per the quality assessment criteria (which are presented in the appendix) of Pittaway et al. (2004). The 94 articles that scored 8 (of a possible 15) or more were selected for the final sample.

Table 2 Inclusion and exclusion criteria

\begin{tabular}{lll}
\hline Criterion & Inclusion & Exclusion \\
\hline Study type & $\begin{array}{l}\text { Peer-reviewed empirical and } \\
\text { theoretical studies }\end{array}$ & All others \\
Language & $\begin{array}{l}\text { English } \\
\text { Source }\end{array}$ & Other languages \\
Date & Articles from scholarly journals & Other sources \\
Relevance & $2010-2018$ & $<2010$ \\
& Mobile retailing & -Not relevant to the research \\
& & question \\
\hline
\end{tabular}

\subsection{Extraction and synthesis}

Per Palmatier et al. (2017), descriptive analysis is useful as a starting point of review due to varying data.

Therefore, key findings, methodological decisions, and implications were summarized on an Excel spreadsheet. The dataset contained quantitative, qualitative, and review articles. Because of the varied data, the cross-case analysis method was used to synthesize each article (Mays et al., 2005). The analysis process, wherein articles were analyzed one by one, formulated constructs around the mobile retailing topic. The literature was scoped to confirm existing terms and theories as well as define new ones (Gioia et al., 2012).

\section{Results}

Table 3 Journals with two or more articles in the review

\begin{tabular}{ll}
\hline Journal title & Number of articles \\
\hline Journal of Retailing and Consumer Services & 11 \\
Journal of Retailing & 7 \\
Journal of Interactive Marketing & 6 \\
International Journal of Electronic Commerce & 5 \\
Computers in Human Behavior & 4 \\
Journal of Internet Commerce & 4 \\
International Journal of Mobile Communications & 3 \\
The Journal of Computer information Systems & 3
\end{tabular}


Telematics and Informatics 3

Advances in Consumer Research $\quad 2$

European Journal of Marketing $\quad 2$

Information \& Management $\quad 2$

Journal of Business Research $\quad 2$

Journal of Marketing 2

Psychology \& Marketing 2

The International Review of Retail, Distribution and Consumer Research 2

Other journals (have published only one article) $\quad 34$

$\begin{array}{ll}\text { Total } & 94\end{array}$

\subsection{A mobile channel's value for the customer}

The goal of increasing the motivation of customers who are using digital technologies and mobile phones is to improve their shopping experiences (Rosenblum and Rowen, 2012). Customers' interactions with available technologies and salespersons together influence overall service quality perception (Pantano and Viassone, 2015). Technologies, such as mobile applications, in-store technologies, social media and Web sites, have enabled omnichannel retailing dynamics that influence both the consumer and the business (Lazaris and Vrechopoulos, 2014). With mobile technologies, retailers can increase perceived value, which increases both loyalty and sales results (Ström et al., 2014). In addition, mobile shopping has strong emotional significance to customers because mobile shopping sites are a source of entertainment (Thakur, 2016). Dennis et al. (2016) noted that shopping positively influences happiness and well-being, and cellphone shopping in particular provides the opportunity to escape reality. Online shopping with computers has a similar effect. In addition, Brasel and Gips (2014) found that touchscreen purchasing generates higher levels of endorsement when compared to laptop touchpads because there is a relationship between the touchscreen and perceived psychological ownership.

Mobile phones increase customers' feelings of control. If consumers search more with their mobile devices, their perceived control over the situation increases, which influences their purchase intentions. Retailers should provide consumers with Wi-Fi in stores to facilitate mobile shopping (Rippé et al., 2017).

Mobile platforms are often developed as an add-on to already existing channels, which limits product range. However, the product range in every channel should be the same regarding prices, product 
data, and promotions (Cook, 2014). In-store marketing stimuli has less of an influence on shoppers using mobile devices in stores because they often pay less attention to it, which causes them to make fewer unplanned purchases. In-store mobile users even forget to purchase some products that they had planned to buy (Bellini and Aiolfi, 2017). Behaviors unrelated to shopping, such as texting, talking, or surfing on the web, can have negative outcomes regarding customers purchasing unplanned products, and those factors might result in a failure to purchase planned items. Related behaviors result in better purchasing decisions and staying on track during shopping (Sciandra and Inman, 2015).

Various authors have concentrated on explaining a customer's motivation to adopt a mobile channel. The literature emphasizes two determinants for mobile channel adoption: hedonic and utilitarian aspects (Iyer et al., 2018; San-Martin et al., 2013; Spaid and Flint, 2014; Yang, 2010). Both hedonic and utilitarian values positively influence the intention of using mobile services (Ltifi, 2018). Previous studies have highlighted that customers' expectations and demands for mobile channels vary per their stage of adoption and the type of products purchased (Yang, 2010, 2012). Different customers have different channel preferences in different shopping, service, and purchase contexts. For example, consumers differ in how they search for, purchase, and use interactive retail services (Berry et al., 2010). Customers' opinions toward mobile retailing vary, and they have different preferences in the types of products purchased (Chou et al., 2016). When they first utilize mobile shopping, usefulness of functions and features is more important; however, in later stages, customers regard enjoyment as more important (Yang, 2010). San-Martin et al. (2013) divided mobile shoppers into three groups: Utilitarian group respects advantages, such as utility; hedonic group prefers more hedonic aspects, and it is important that they are satisfied with their experience; group three sees no advantages in mobile shopping compared to other forms of shopping.

The stage of adoption can influence a customer's behavior. Early adopters can spread their opinions to non-users, and the role of early adopters has been shown to significantly influence mobile shopping adoption among others (Natarajan et al. 2017). Becoming confident in mobile shopping allows customers to explore more functions and features, which enriches their mobile shopping experience 
(Yang, 2012). Ono et al. (2012) divided customers' motivation to browse stores into two categories: utilitarian motivation to follow information about prices, trends, and fashion and hedonic adventure motivation, such as motivation to follow exciting and stimulating content in mobile stores. Lai et al. (2012) presented a different viewpoint for consumer preferences when they stated that hedonic consumers are heavy shoppers, and utilitarian consumers are light users. They stated that, instead of targeting marketing communications based on the stage of mobile channel adoption or product categories, retailers should target communications based on types of consumers.

\subsection{Utilitarian aspects of mobile shopping adoption}

Mobile devices are changing the shopping journey from one in which consumers enter retail stores to one in which retailers enter the consumer's environment anytime and anywhere. Mobile consumer activities that satisfy customer needs include mobile websites, mobile emailing and messaging, mobile advertising and couponing, mobile customer service, and mobile social network management. Per the technology acceptance model (TAM), perceived usefulness and ease of use are key factors in determining the adoption of mobile technology (Shankar et al., 2010). Hung et al. (2012) perceived usefulness as an insignificant variable of mobile shopping continuance. However, it is significant to consumers' intention to adopt mobile shopping. Retailers should provide additional advantages compared to traditional offline stores to create the impression of usefulness. "Always available" and "portable" are features of mobile shopping that retailers should promote to increase the impression of usefulness. Perceived ease of use is a significant variable in the prediction of consumers' intention to adopt mobile shopping. Screen size, visual displays, and keyboard interfaces help create a favorable shopping environment.

\subsubsection{Information sharing}

Previous mobile retailing research has shown that information sharing is an essential feature of mobile channels. Retailers can facilitate a customer's purchase process with these informative technology solutions (Fuentes and Svingsted, 2017; Kowatsch et al., 2011; Kowatsch and Maas, 2010; Pousttchi and Hufenbach, 2014; Varadarajan et al., 2010; Zhang et al., 2013). Retailers can offer plentiful information 
via a mobile service because product information systems can be combined with advertising (Pousttchi and Hufenbach, 2014), and interactive product information is seen as useful for in-store purchase decisions (Kowatch et al., 2011). Having mobile recommendation agents available for product information regarding in-store purchases increases sales volume through an increase in purchase

frequency (Kowatsch and Maas, 2010). In addition, third-party technologies and applications are facilitating product comparison and research with mobile devices. This is both a threat and an opportunity because technology diminishes information asymmetry between the retailer and the customer. If a customer is not satisfied after comparing prices on a mobile device, he/she may walk away from the retail store. However, retailers are now able to compete more effectively with interactive technologies (Varadarajan et al., 2010). Notably, the findings of Fuentes and Svingsted (2017) support these results. They found that mobile customers are better informed about prices, technical properties, product availability, and environmental consequences, which has created a challenge for servicepersons. Retailers are trying to serve customers for example with Quick Response Codes (QR codes) and web links in stores.

Smartphones reveal a significant amount of personal information about customers, such as their location, device serial numbers, internal mobile equipment identity, Subscriber Identity Module (SIM) card identifiers, social relationships, lifestyle, preferences, and behavior patterns. Thus, customers are afraid of exposing their personal information (Zhang et al., 2013).

\subsubsection{Marketing communication personalization}

Previous studies have revealed that mobile technologies allow retailers to personalize their marketing activities and services (Morosan and Agnes, 2016) by sending targeted promotional offers and coupons based on a customer's location (Cao, 2014; Grewal et al., 2011; Hui et al., 2013; Izquierdo-Yusta et al., 2015; Khajehzadeh, 2015; Rigby, 2011; Taylor and Levin, 2014; Zubcsek et al., 2015). However, mobile advertising on a large scale and without any segmentation can cause consumers to not open messages (Izquierdo-Yusta et al., 2015). Zubcsek, Katona, and Sarvary (2015) stated that location history reveals 
consumer preferences effectively. In addition, location data allows retailers to send offers when a customer enters their physical store (Rigby, 2011). Kim and Han (2014) noted that demographic-based data helps retailers personalize mobile advertisements, which helps them avoid presenting unwanted marketing communication. Per Bart et al. (2014), mobile display advertising could be effective for certain products (high involvement and utilitarian products). Hedonic and lower involvement products could be positioned as utilitarian and higher involvement products in mobile channel advertising.

Smartphone-generated content helps retailers measure consumers' opinions, which facilitates marketing personalization (Melumad et al., 2015). Mobile promotions that are targeted at increasing travel distance increase unplanned spending. Therefore, shopping basket data should be analyzed to identify product combinations that are not normally purchased together. With this data, these products can be offered at the locations of both products (Hui et al., 2013). Subjective norm, perceived usefulness, and perceived ease of use support customers' mobile coupon usage intentions; therefore, retailers need to promote both usefulness and ease of use to encourage customers to use mobile coupons (Im and Ha, 2013).

Morosan and Agnes (2016) stated that mobile service personalization results in higher satisfaction, reduced costs, and direct distribution. Per Andrews et al. (2012), while customers do perceive value when they receive personalized mobile marketing communications, more research should be done to identify the sources, elements, and degrees of this value because different consumers find different kinds of value through different avenues. Some are expecting functional value, and they want to have control over this activity, while others are expecting conditional value, such as how much and what kind of marketing they receive.

Importantly, mobile adoption may rise in the future because opportunities to receive coupons and promotions, search for prices and reviews, and compare products play significant roles in retail commerce (Einav et al., 2014). More than 50\% of cell phone owners had smartphones in 2015, and over $70 \%$ of those smartphone owners used their mobile devices for shopping (Brynjolfsson et al., 2015); therefore, it is obvious that mobile usage will continue grow in the future. 


\subsubsection{Ease of use}

One feature of mobile channels that has great potential compared to other retailing channels is ease of use. From this utilitarian perspective, consumers will adopt mobile shopping if they believe that it will increase their shopping performance (Yang, 2010). Consumers are able to shop anytime and anywhere with mobile devices (Bang et al., 2013a; Blázquez, 2014; Huang, 2016; Shankar et al., 2010), and the ability to save time and money are core benefits of mobile channel use (Dmour et al., 2014; Groß, 2015a; Pantano and Priporas, 2016; Yang, 2010). Motivations for mobile shopping include savings of time and money and customized services (Dmour et al., 2014; Pantano and Priporas, 2016). Customers' habits and cost-benefit calculations can influence m-commerce adoption. The benefit is ease of use, while the costs are the limited user interface of mobile devices (Bang et al., 2013a). In addition, search cost is a significant determinant for m-commerce adoption (Bang et al., 2013b). When customers believe that mobile shopping will help them save time, obtain promotion information, and/or receive customized product information, it helps them adopt the technology (Yang 2010). Consumers are willing to adopt mobile shopping to avoid queues in offline stores (Pantano and Priporas, 2016). Groß (2015a) highlighted the importance of ease of use in mobile shopping services as it relates to an enjoyable mobile shopping experience. Per his results, utilitarian aspects are more important than hedonic aspects in the creation of positive attitudes toward mobile shopping, with the main aspect being the ability to save time and money. However, other existing studies have shown different results. For example, Yang (2012) showed that, in the beginning of mobile channel adoption, customers prefer utilitarian benefits, but when they become familiar with mobile shopping, they take on a more hedonistic perspective. 
Table 4 The main studies related to the utilitarian aspects of mobile shopping adoption

\begin{tabular}{|c|c|c|}
\hline Study and context & Method & Key takeaways \\
\hline Andrews et al., 2012 & $\begin{array}{l}15 \text { qualitative } \\
\text { customer } \\
\text { interviews }\end{array}$ & $\begin{array}{l}\text { Customers perceive value when they are receiving mobile marketing communications. Different consumers find value in different ways; } \\
\text { some expect functional value, and they want to have control over this activity, while others expect conditional value, such as how much } \\
\text { and what kind of marketing they receive. }\end{array}$ \\
\hline Bang et al., 2013b & $\begin{array}{l}1,454,803 \\
\text { transactions of } \\
30,000 \text { users }\end{array}$ & $\begin{array}{l}\text { Customers' habits and cost-benefit calculation influence m-commerce adoption. A benefit is the ability to use mobile technologies } \\
\text { anywhere and at any time, while the costs include the limited user interfaces of mobile devices. In addition, search cost is a significant } \\
\text { determinant for m-commerce adoption. }\end{array}$ \\
\hline Bart et al., 2014 & $\begin{array}{l}39946 \text { participants } \\
\text { in field tests }\end{array}$ & $\begin{array}{l}\text { Mobile display advertising could be effective for high involvement and utilitarian products. Hedonic and lower involvement products } \\
\text { could be positioned as utilitarian and higher involvement products in mobile channel advertising. }\end{array}$ \\
\hline Blázquez, 2014 & $\begin{array}{l}14 \text { interviews } \\
\text { with managers of } \\
\text { a case company }\end{array}$ & Customers value the ability to shop anywhere and at any time with mobile devices. \\
\hline $\begin{array}{l}\text { Brynjolfson et al., } \\
2015\end{array}$ & $\begin{array}{l}\text { Customer data of } \\
\text { a medium-sized } \\
\text { retail company }\end{array}$ & $\begin{array}{l}\text { More than } 50 \% \text { of cell phone owners in the U.S. have smartphones, and over } 70 \% \text { of those users have used their mobile devices for } \\
\text { making comparisons in shopping. }\end{array}$ \\
\hline Cao, 2014 & $\begin{array}{l}14 \text { interviews } \\
\text { with managers of } \\
\text { the case company }\end{array}$ & Retailers can provide a more customized offering and greater convenience for customers with mobile applications. \\
\hline Dmour et al., 2014 & $\begin{array}{l}250 \text { responses to a } \\
\text { survey }\end{array}$ & $\begin{array}{l}\text { Users' perceived mobile application quality has a significant effect on mobile shopping continuance. The benefits of mobile shopping } \\
\text { include savings of time and money and easy facilitation of the purchasing process. }\end{array}$ \\
\hline Einay et al., 2014 & $\begin{array}{l}\text { Random } 1 \% \\
\text { sample of eBay } \\
\text { users }\end{array}$ & $\begin{array}{l}\text { Mobile adoption may rise in the future due to e-commerce. Opportunities to receive coupons and promotions, search for prices and } \\
\text { reviews, and compare products play significant roles in retail commerce. }\end{array}$ \\
\hline $\begin{array}{l}\text { Fuentes and Svigsted, } \\
2017\end{array}$ & $\begin{array}{l}51 \text { interviews } \\
\text { with customers }\end{array}$ & Mobile customers are better informed about prices, technical properties, product availability, and environmental consequences. \\
\hline Grewal et al., 2011 & Literature review & $\begin{array}{l}\text { Mobile applications offer opportunities for location-based price promotions, such as coupons and direct messages to customers' mobile } \\
\text { devices when they are near a store. }\end{array}$ \\
\hline Groß, 2015a & $\begin{array}{l}128 \text { smartphone } \\
\text { users with } \\
\text { previous } \\
\text { experience in m- } \\
\text { purchasing }\end{array}$ & $\begin{array}{l}\text { Groß highlighted the importance of ease of use regarding mobile shopping services and enjoyment. Utilitarian aspects are more important } \\
\text { than hedonic aspects in the creation of positive attitudes toward mobile shopping due to savings in both time and money. }\end{array}$ \\
\hline
\end{tabular}


Hui et al., 2013

An initial survey

with 275

consumers, and a

second with 81

Im and Ha, 2013

Izquierdo-Yusta et

al., 2015

Khajehzadeh et al.,

2015

Kim et al., 2015

Kim and Han, 2014

Kowatsch and Maas,

2010

Kowatsch et al., 2011

611 responses to

survey

612 responses to a

survey

288 responses to survey

403 responses to survey

256 responses to survey

47 students in a

lab experiment

116 subjects in an experiment

Lemon and Verhoef, Literature review

2016

Melumad, Inman, and 367 participants

Pham, 2015

writing a

restaurant review

Morosan and Agnes,

2016

421 responses to survey

Pantano and Priporas, 29 consumer 2016 interviews

Pousttchi and Hufenbach, 2014

Interviews with four m-commerce
Mobile promotions that are targeted at increasing travel distance increase unplanned spending.

Subjective norm, perceived usefulness, and perceived ease of use are behind customers' mobile coupon usage intentions. For the first time, mobile coupon users' perceived risk is related to intention to disclose personal information.

Mobile advertising on a large scale without segmentation leads consumers to decline to open messages.

Location-based technologies, such as mobile devices, facilitate the targeting of offers to the right customers. Personalization is important for utilitarian consumers, but it is less effective for hedonic consumers.

Personalization, simplicity (access to shops anywhere and anytime), and connectivity significantly affect the utilitarian value of mobile shopping Mobile advertisement should be pleasant, credible, and informative to attract customers. With demographic-based data, retailers are able to personalize mobile advertisements, which helps them avoid sending unwanted messages.

Having mobile recommendation agents available to offer product information for in-store purchase situations increases sales volume through an increase in consumer frequency.

Interactive product information on mobile devices is perceived as more useful for in-store purchase decisions than static information.

Mobile channels are better for searching than for making purchases.

Smartphone-generated content helps retailers measure consumers' opinions. It is more emotional and appealing for consumers and received more votes than PC-generated posts.

Mobile apps allow service personalization, which results in higher satisfaction, reduced costs, and direct distribution in the hotel context.

Consumers are willing to adopt mobile shopping to avoid queues at offline stores. and retail experts

(two from
Retailers can offer information via a mobile service. Product information systems can be combined with advertising. 
academia and two

from industry)

Rigby, 2011

Shankar et al., 2010

Literature review

Marketers are able to send offers to customer's mobile devices with location-based platforms when customers check in at stores.

Traditional retailing is based on consumers entering the retail environment, but mobile devices are changing this situation to one in which retailers are entering the consumer's environment anytime and anywhere. Per the TAM, perceived usefulness and ease of use are the key factors in determining the adoption of mobile technology.

Tarute et al., 2017

246 responses to survey

Taylor and Levin, 2014

Varadarajan et al., 2010

Verkijika, 2018

Wong et al., 2014

Yang, 2010

Zhang et al., 2013

Zubcsek et al., 2015

7 participants

using location

apps during the

research

Yang and Kim, 2012400 mobile service users'

responses to an online survey

Mobile application usability and visuals influence emotional consumer engagement.

Customers' interest in a retailer's mobile app correlates with the intention to engage in purchasing and information-sharing activities. Customers are seeking mobile apps that help them complete a transaction.

Third-party technologies and applications facilitate product comparison and research with mobile devices. This is both a threat and an opportunity because technology diminishes information asymmetry between the retailer and the customer. If the customer is not satisfied with th price after checking it via the mobile app, he/she may walk away from the retail store.

372 responses to a Perceived risk and perceived trust significantly affect behavioral intention toward mobile shopping adoption.

urvey

Perceived usefulness significantly affects consumers' intention to adopt mobile shopping. Perceived ease of use is a significant variable for predicting consumers' intention to adopt mobile shopping. Conversely, perceived risk is insignificant regarding consumers' intentions to adopt mobile shopping.

A customer's belief that mobile shopping will help save them time, obtain promotion information, and/or receive customized product information increases his/her adoption of mobile shopping.

Smartphones reveal personal information about customers, such as their location, device serial numbers, internal mobile equipment identity, SIM card ID, social relationships, lifestyle, preferences, and behavior patterns. This aspect provides opportunities as well as challenges for retailers because customers fear exposing their personal information.

Consumers' location history reveals consumer preferences effectively. Personal advertising can be done based on location history. Mobile shopping saves search time by providing quick access to store locations and the ability to browse products at many retailers. For example
GPS on mobile phones helps customers locate the nearest stores, and mobile coupons help save money and make price comparisons both faster and easier. 


\subsection{Hedonic aspects of mobile shopping adoption}

The emotional aspect plays a significant role in mobile channel adoption because mobile shopping is a source of entertainment for customers (Thakur, 2016). Entertainment is the most important determinant of adoption, per Yang (2010), and mobile channels have created a new way to explore products (Yang and Kim, 2012).

The findings of Kang et al. (2015) revealed that the intention to download and use mobile retailing apps is a result of the hedonic motives and positive feelings being evoked by mobile retail apps. In addition, Lee (2017) noted that hedonic motives guide consumers toward mobile channels and lead to the continuance of mobile shopping (Lee and Kim, 2018; Shang and Wu, 2017). When consumers are familiar with mobile shopping, they prefer values like fun (Spaid and Flint, 2014). Agrebi and Jallais (2015) noted that perceived enjoyment in mobile shopping leads to intention to use it. Therefore, from a hedonic perspective, it is important to develop enjoyable habituation to mobile shopping (Hubert, 2017).

Mobile website interactivity is a predictor of enjoyment of the site (Kang, 2015). Usability and visuals of mobile applications influence emotional customer engagement (Tarute et al., 2017), and customer's feeling of control of mobile marketing results in deepening their involvement (Persaud and Azhar, 2012). Yang (2010) stated that entertainment aspects are the most salient determinants of mobile shopping adoption. These hedonic aspects increase a customer's interaction with other customers. In addition, Yang and Forney (2013) found that hedonic performance expectancy was the most important predictor of intention to adopt mobile shopping.

Mobile shopping has been found to improve customers' quality of life; it is a great source of happiness and well-being, and it even provides the opportunity to escape reality (Dennis et al., 2016). Touchscreen purchasing generates higher levels of endorsement than purchases with laptop touchpads, which influence perceived psychological ownership (Brasel and Gips, 2014). Voropanova (2015) stated that retailers can improve consumer productivity by increasing shopping's emotional benefits. Per Blázquez (2014), the entire store experience should be redefined because, thanks to mobile technologies, 
it is becoming part of a larger and more connected experience. In the future, mobile experiences will become more entertaining and satisfying because of the new developing functions of mobile applications - better usage of mobile apps results in higher satisfaction (Pantano and Priporas, 2016).

\subsubsection{Trust}

Trust is also an important factor in mobile shopping adoption (Blaise et al., 2018; Chong, 2013; Hung et al., 2012; Suki, 2011; Verkijika, 2018; Yang et al., 2015). It directly influences behavior toward mobile shopping extension and indirectly influences it via perceived benefits and risks. Thus, enhancing trust reduces perceived risk toward mobile shopping services (Blaise et al., 2018; Yang et al., 2015).

Chong (2013) stated that, for retailers, it is critical to ensure that consumers are satisfied with and have had their expectations for m-commerce met. Chong also noted that customer satisfaction leads to trust in the mobile retailing context, which motivates customers to continue their m-commerce usage. Retailers can make customers aware of security precautions to reduce perceived security risks. Hung et al. (2012) also noted that trust and satisfaction are the most important factors of mobile shopping continuance, and trust is a result of satisfaction. In addition, the results of Suki (2011) support the strong relationship between satisfaction and trust.

Perceived integration between channels has a strong positive effect on trust in mobile retailing (Yang et al., 2015). Customers choose channels depending on their current situation, making easy movement between channels critical (Piotrowicz and Cuthbertson, 2014). Channel integration increases perceived service quality, which increases overall outcomes (Herhausen et al., 2015). It has a positive influence on retailers' performance and competencies (Oh et al., 2012). 
Table 5 The main studies related to the hedonic aspects of mobile shopping adoption

\begin{tabular}{|c|c|c|}
\hline Study and context & Method & Key takeaways \\
\hline $\begin{array}{l}\text { Agrebi and Jallais, } \\
2015\end{array}$ & $\begin{array}{l}\text { Survey of } 400 \\
\text { French purchasers } \\
\text { and non- } \\
\text { purchasers }\end{array}$ & $\begin{array}{l}\text { Perceived enjoyment positively influences the intention of purchasers to use mobile channels only. Non-purchasers' actions are } \\
\text { based on utilitarian factors because they are more task-oriented. }\end{array}$ \\
\hline Blaise et al., 2018 & $\begin{array}{l}\text { Survey of } 165 \\
\text { North American } \\
\text { adults }\end{array}$ & Trust reduces perceived risk, and thus facilitates mobile shopping adoption. \\
\hline Blázquez, 2014 & $\begin{array}{l}14 \text { interviews } \\
\text { with managers of } \\
\text { a case company }\end{array}$ & $\begin{array}{l}\text { Consumers can shop anytime and anywhere with mobile devices. Thus, the store experience should be redefined; it is becoming } \\
\text { part of a larger and more connected customer experience. }\end{array}$ \\
\hline $\begin{array}{l}\text { Brasel and Gips, } \\
2013\end{array}$ & $\begin{array}{l}175 \text { Amazon } \\
\text { MTurk users }\end{array}$ & $\begin{array}{l}\text { Touchscreen purchasing generates higher levels of endorsement when compared to laptop touchpads. There is a relationship } \\
\text { between a touchpad and perceived psychological ownership. }\end{array}$ \\
\hline Chong, 2013 & $\begin{array}{l}\text { Survey of } 410 \\
\text { respondents }\end{array}$ & $\begin{array}{l}\text { Trust is one of the most important factors in m-commerce usage; retailers can make customers aware of security issues to reduce } \\
\text { perceived security risks. }\end{array}$ \\
\hline Dennis et al., 2016 & $\begin{array}{l}\text { Survey with } 1,386 \\
\text { respondents }\end{array}$ & $\begin{array}{l}\text { Shopping has a positive influence on happiness and well-being. Cellphone shopping in particular provides an opportunity to escape } \\
\text { reality. Online shopping on a computer produces a similar effect. }\end{array}$ \\
\hline Hubert et al., 2017 & $\begin{array}{l}410 \text { responses to a } \\
\text { survey }\end{array}$ & $\begin{array}{l}\text { From a hedonic perspective, enjoyment of mobile shopping is less important than developing habituation. With temporary } \\
\text { discounts, retailers are able to ensure customers' repeated purchases. }\end{array}$ \\
\hline Hung et al., 2012 & $\begin{array}{l}244 \text { responses to a } \\
\text { survey }\end{array}$ & $\begin{array}{l}\text { Perceived usefulness is not a significant variable of mobile shopping continuance, but trust and satisfaction are the most important } \\
\text { factors. }\end{array}$ \\
\hline Kang, 2015 & $\begin{array}{l}\text { Survey of } 853 \\
\text { women using } \\
\text { mobile internet in } \\
\text { the U.S. }\end{array}$ & $\begin{array}{l}\text { The intention to download and use mobile retailing apps is a result of consumers' hedonic motives and the positive feelings that are } \\
\text { evoked by mobile retail apps. Mobile website interactivity is a predictor of enjoyment of a mobile website. }\end{array}$ \\
\hline Lee and Kim, 2018 & $\begin{array}{l}216 \text { responses to a } \\
\text { survey }\end{array}$ & $\begin{array}{l}\text { Hedonic shopping orientation correlates with the need for mobile app atmospherics, which are important to the reuse of } \\
\text { applications. }\end{array}$ \\
\hline Lee, 2017 & $\begin{array}{l}635 \text { consumers' } \\
\text { with online or } \\
\text { mobile shopping } \\
\text { experience }\end{array}$ & Hedonic motives guide customers toward mobile channel use, whereas utilitarian motives lead to the use of online channels. \\
\hline
\end{tabular}


responses to a

survey

McLean et al., $2018 \quad 1024$ responses to a survey

Pantano and Priporas, 29 consumer

2016

interviews

Persaud and Azhar, Survey of 350

2012

Shang and $\mathrm{Wu}, 2017$

Spaid and Flint, 2014

Suki, 2011

Thakur, 2016

Voropanova, 2015

Yang and Forney, 2013

Yang and Kim, 2012

Yang et al., 2015 young educated

Canadians

203 responses to a survey

32 customer interviews survey customer

interviews, a

survey of 304

respondents, and a

survey of 433

respondents

Literature review

400 responses to a survey

400 mobile

service users'

responses to a

survey

309 responses to a

survey
200 responses to a

Three studies: 10
Utilitarian factors, such as ease of use, convenience and customization, are behind hedonic experience. These are driving a customer's level of enjoyment during mobile app usage.

In the future, mobile experiences will become more entertaining and satisfying because functions of mobile applications are developing and satisfying more customer's needs.

When consumers have more control over mobile shopping, they are more willing to deepen their involvement. Engagement is important in this kind of customer relationship.

Enjoyment of shopping increases customers' intentions to continue the use of mobile shopping

Customers use mobile internet devices for different reasons: hedonic and utilitarian. Mobile internet devices create both challenges and new tools. When customers are familiar with technologies, they prefer values such as "fun."

Trust, responsiveness, and brand image influence customer relationships in m-commerce.

Mobile shopping has a strong emotional significance for customers because mobile sites are a source of entertainment.

Retailers can improve consumer productivity by increasing shopping's emotional benefits.

Hedonic performance expectancy is the most important predictor of the intention to adopt mobile shopping.

Adventure shopping via mobile sites entertains customers because they are able to explore stores and product reviews in a new way.

Trust indirectly influences behaviors toward mobile shopping extension. Enhancing trust reduces perceived risk toward mobile shopping services. In addition, the relationship between mobile and web shopping platforms is important because perceived integration indirectly affects behaviors toward mobile channels. 


\section{Discussion}

\subsection{Theoretical contributions}

This study contributes to an understanding of the mobile channel adoption. The recent literature on mobile retailing underlines the role of both the utilitarian and the hedonic value of mobile channels for customers. A customer's previous experience, stage of channel use, and the retailing context determine which features are the most valuable for mobile channel adoption in different stages (Figure 1).

In the initial stages, when customers are not familiar with mobile technologies and/or they lack experience in using them, they prefer utilitarian benefits (Yang, 2012), such as savings of time (Dmour et al., 2014; Pantano and Priporas, 2016) and personalized offerings (Melumad et al., 2015; Morosan and Agnes, 2016). In these stages, consumers perceive security risks (Chong 2013); however, trust reduces perceived risk toward mobile shopping services (Yang et al., 2015).

At the adoption stage, customers are comparing the costs of mobile channel use, such as limited user interfaces (Bang et al., 2013b), as well as benefits, such as easy shopping anytime and anywhere (Blázquez, 2014; Shankar et al., 2010; Bang et al., 2013b; Huang, 2016). Customers expect highly personalized mobile marketing communications (Andrews et al., 2012), but they are afraid of losing their personal information. Retailers can use customers' location data to personalize offers (Cao, 2014; Grewal et al., 2011; Hui et al., 2013; Khajehzadeh, 2015; Rigby, 2011; Taylor and Levin, 2014; Zubcsek, Katona, and Sarvary, 2015).

Our analysis also provides several insights into the later stages of adoption, when customers are accustomed to the technology. In these stages, customers start to value more hedonic aspects (Yang, 2012), such as enjoyment (Yang, 2010). This study shows that the purchase itself is commonly linked with hedonic value. The literature also shows that touchscreen purchasing generates higher levels of endorsement compared to laptops (Brasel and Gips, 2014), and mobile shopping continuance and hedonic benefits have a strong relationship (Lee and Kim, 2018; Shang and Wu, 2017). 
Nevertheless, it was found that mobile shopping is used more for searching than actual purchases (Lemon and Verhoef, 2016). From a hedonic perspective, mobile shopping is seen as an adventure-a possibility to escape the real world (Dennis et al., 2016). Mobile shopping engrosses customers and deepens their involvement because they feel that they have more control over their shopping (Persaud and Azhar, 2012).

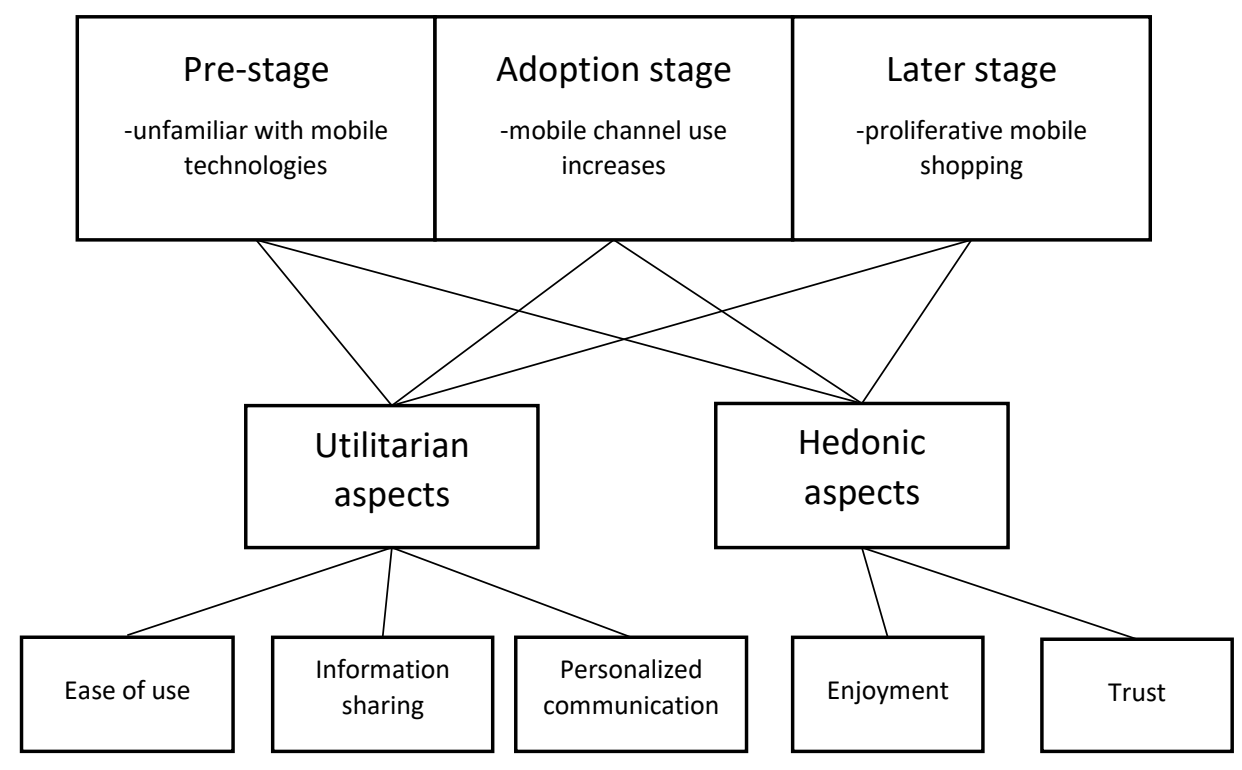

Figure 1. Mobile shopping adoption aspects per adoption stage

\subsection{Managerial implications}

Because customers have different preferences in different stages of mobile channel adoption, retailers should personalize marketing communications based on a customer's current stage. As Kim et al. (2017) suggested, instead of a single-app strategy, retailers are launching a collection of both shopping and nonshopping apps, which enable them to collect significant amounts of data about digital experiences and browsing behavior. The key factor in mobile success was found to be well-timed utilization of this data. Bilgicer et al. (2015) noted that retailers can influence channel adoption with marketing activities. 
A mobile channel is not seen as a purchasing channel but rather as a searching channel. Because mobile purchasing generates high levels of endorsement, opportunities abound for retailers. If they can successfully utilize it in their business, they can provide deeper and more satisfying customer experiences.

Because of the growing popularity of mobile shopping, in-store experiences are also in transition. The ability to reach a mobile channel anywhere and anytime leads to an increase in in-store mobile use, which creates a demand for new mobile solutions that facilitate searching, locating, comparing, and purchasing products in stores.

\subsection{Limitations of the study and future research directions}

The taken review approach resulted in certain limitations. The number of articles published and searched were limited. The data were collected from articles published between the years 2010 and 2018. Because of the exponential growth of mobile shopping, the context changed significantly between those years. Consequently, newer publications should be given more importance. In addition, the chosen classification framework for articles can be criticized because the scoring was also guided by the authors' own subjective process.

We hope that this research has provided convincing answers to questions about the significance of the mobile adoption stage regarding customers' preferences. Future research can provide interesting insights with both new research methods and research topics. One interesting viewpoint would be a longitudinal study. Because the previous literature and our framework for mobile channel adoption aspects (Figure 1) clearly show that customers in different stages of mobile channel adoption have different preferences in terms of value, it would be beneficial to examine how their behavior and preferences change during their customer journey.

One future research topic would be the examination of the influence of mobile word-of-mouth (WOM). Bilgicer et al. (2015) showed that neighboring and peer customers accelerate the diffusion of the new retail channel. In addition, Riquelme et al. (2015) examined the effects of satisfaction and their 
influence on WOM in the online context. Therefore, future research might shed more light on how satisfaction toward mobile channels has a similar positive influence on mobile WOM.

Per Lemon and Verhoef (2016), mobile channels are used more for searching than for making purchases. From a retailer's perspective, it would be beneficial to have the ability to remove all barriers to mobile purchases.

Our model investigated customer behavior in which only one retailer was considered. However, that is not the circumstance in retail markets. Melis et al. (2015) noted that, when customers had more experience with online shopping, they made comparisons within the online channel across different retail chains. It would be interesting to determine whether the situation is the same in mobile channels.

Finally, future research could consider the relationship between online and mobile channels. Do mobile channels cannibalize the web channel? Although some evidence exists on that topic (Huang et al., 2016), more research is required. Pauwels and Neslin (2015) showed that online and offline stores are complements instead of substitutes. Because all omnichannel literature highlights the positive effect of channel integration, how this should be seen via Huang's (2016) results, that mobile channel cannibalizes online channel, should be explored.

\subsection{Conclusion}

Mobile retailing adoption has been relatively actively discussed during the last decade. The purpose of this study is to provide a comprehensive updated review and analysis of mobile retailing adoption. Although research on mobile channel utilization has increased significantly in recent years and many new studies on this topic have been published, research has not yet provided a clear structure regarding how consumers' expectations have advanced in relation to mobile retailing adoption. Thus, this study synthetizes the mobile retail adoption literature and develops a framework for it. This study provides a systematic review of literature on mobile retailing adoption published from January 2010 to December

2018. The analyzed 94 relevant studies present wide view of existing mobile retailing adoption literature. The analysis of the literature highlights hedonic and utilitarian viewpoints behind mobile retailing 
adoption. Our study develops a theoretical framework (Figure 1) of the adoption that highlights how hedonic and utilitarian aspects are related in different stages of mobile retailing adoption. Our findings enhance the understanding of how retailers can serve customers in each stage. In addition, our framework provides opportunities and provokes questions for further research as well as shifts the focus from technology adoption-oriented topics toward customer journeys. 


\section{References}

Agrebi, S., and J. Jallais. 2015. Explain the intention to use smartphones for mobile shopping. Journal of Retailing and Consumer Services 22(1): 16-23.

Andrews, L., Drennan, J., and R. Russell-Bennett. 2012. Linking perceived value of mobile marketing with the experiential consumption of mobile phones. European Journal of Marketing 46(3): 357-386.

Bang, Y., Lee, D. Han, K. Hwang, M., and J. Ahn. 2013a. Channel Capabilities, Product Characteristics, and the Impacts of Mobile Channel Introduction. Journal of Management Information Systems 30(2):

101-125.

Bang, Y., Han, K., Animesh, A., and M. Hwang. 2013b. From Online to Mobile: Linking Consumers' Online Purchase Behaviors with Mobile Commerce Adoption. PACIS 2013 Proceedings. 128.

Bart, Y., Stephen, A., and M. Sarvary. 2014. Which Products Are Best Suited to Mobile Advertising? A Field Study of Mobile Display Advertising Effects on Consumer Attitudes and Intentions. Journal of Marketing Research 51(3): 270-285.

Bellini, S., and S. Aiolfi. 2017. The Impact of Mobile Device Use on Shopper Behaviour in Store: An empirical Research on Grocery Retailing. International Business Research 10(4): 58-68.

Berry, L., Bolton, R., Bridges, C., Meyer, J., Parsuraman, A., and K. Seiders. 2010. Opportunities for Innovation in the Delivery of Interactive Retail Services. Journal of Interactive Marketing 24(2): 155167.

Bilgicer, T., Jedidi, K., Lehmann, D., and S. Neslin. 2015. Social Contagion and Customer Adoption of New Sales Channels. Journal of Retailing 91(2): 254-271.

Blaise, R., Halloran, M., and M. Muchnick. 2018. Mobile Commerce Competitive Advantage: A Quantiattive Study of Variables that Predict M-Commerce Purchase Intentions. Journal of Internet Commerce 17(2): 96-114.

Blázquez, M. 2014. Fashion Shopping in Multichannel Retail: The Role of Technology in Enhancing the Customer Experience. International Journal of Electronic Commerce 18(4): 97-116.

Brasel, S., and J. Gips. 2014. Tablets, touchscreens, and touchpads: How varying touch interfaces trigger psychological ownership and endowment. Journal of Consumer Psychology 24(2): 226-233.

Brynjolfsson, E., Hu, Y., and M. Rahman. 2015. Competing in the age of omnichannel retailing. MIT Sloan Management Review 54(4): 23-29.

Cao, L. 2014. Business Model Transformation in Moving to a Cross-Channel Retail Strategy: A Case Study. International Journal of Electronic Commerce 18(4): 69-96.

Cao, Y., and Y. Lu. 2015. The effects of differences between e-commerce and m-commerce on the consumer's usage transfer from online to mobile channel. International Journal of Mobile Communications 13(1): 51-70.

Carvalho, J. and M. Campomar. 2014. Multichannel at Retail and Omni-channel: Challenges for Marketing and Logistics. Business and Management Review 4(3): 103-113.

Chau, N., Seashadri, S., Broekemier, G., and S. Pamarnpathomkul. 2018. An Exploratory Study of Mobile Behaviors of Young Adults in Thailand. Journal of Internet Commerce 17(4): 339.-355.

Chong, A. 2013. Understanding mobile commerce continuance intentions: An empirical analysis of Chinese consumers. The Journal of Computer Information Systems Summer 2013: 22-30.

Chou, Y.-C., Chuang, H., and B. Shao. 2016. The impact of e-retail characteristics on initiating mobile retail services: A modular innovation perspective. Information \& Management 53(4): 481-491

Cook, G. 2014. Customer experience in the omni-channel world and the challenges and opportunities this presents. Journal of Direct, Data and Digital Marketing Practice 15(4): 262-266.

Dmour, H., Alshurideh, M., and F. Shishan. 2014. The Influence of Mobile Application Quality and Attributes on the Continuance Intention of Mobile Shopping. Life Science Journal 11(10): 172-181. 
Dennis, C., Alamanos, E., Papagiannidis, S., and M. Bourlakis. 2016. Does social exclusion influence multiple channel use? The interconnections with community, happiness, and well-being. Journal of Business Research 60(3): 1061-1070.

Einav, L, Levin, J., Popov, I., and N. Sundaresan. 2014. Growth, Adoption and Use of Mobile ECommerce. American Economic Review 104(5): 489-494.

Fuentes, C., and A. Svingstedt. 2017. Mobile phones and the practice of shopping: A study of how young adults use smartphones to shop. Journal of Retailing and Consumer Services 38(1): 137-146.

Gioia, D. A., Corley, K. G., and A. L. Hamilton. 2012. Seeking qualitative rigor in inductive research: Notes on the Gioia methodology. Organizational Research Methods 16(1): 15-31.

Goh, K., Chu, J., and J. Wu. 2015. Mobile Advertising: An Empirical Study of Temporal and Spatial Differences in Search Behavior and Advertising Response. Journal of Interactive Marketing 30(1): 34-35. Grewal, D., Ailawadi, K., Gauri, D., Hall, K., Kopalle, P., and J. Robertson. 2011. Innovations in Retail Pricing and Promotions. Journal of Retailing 87S(1): S43-S52.

Groß, M. 2015a. Exploring the acceptance of technology for mobile shopping: an empirical investigation among Smartphone users. The International Review of Retail, Distribution and Consumer Research 25(3): 215-235.

Groß, M. 2015b. Mobile shopping: a classification framework and literature review. International Journal of Retail \& Distribution Management 43(3): 221-241.

Herhausen, D., Binder, J., Schoegel, M., and A. Hermann. 2015. Integrating Bricks with Clicks: RetailerLevel and Channel-Level Outcomes of Online-Offline Channel Integration. Journal of Retailing 91(2): 309-325.

Hino, H. 2015. Assessing Factors Affecting Consumer's Intentions to Adopt Biometric Authentication Technologies in E-Shopping. Journal of Internet Commerce 14(1): 1-20.

Hubert, M., Blut, M., Brock, C., Backhaus, C., and T. Eberhard. 2017. Acceptance of Smartphone-Based Mobile Shopping: Mobile Benefits, Customer Characteristics, Perceived Risks, and the Impact of Application Context. Psychology \& Marketing 34(2): 175-194.

Hui, S. 2013. The Effect of In-Store Travel Distance on Unplanned Spending: Applications to Mobile Promotion Strategies. Journal of Marketing 77(2): 1-16.

Huang, L., Lu, X., and S. Ba. 2016. An empirical study of the cross-channel effects between web and mobile shopping channels. Information \& Management 53(2): 265-278.

Hung, M., Yang, S., and T. Hsieh. 2012. An examination of the determinants of mobile shopping continuance. International Journal of Electronic Business Management 10(1): 29-37,

Im, H., and Y. Ha. 2013. Enablers and inhibitors of permission-based marketing: A case of mobile coupons. Journal of Retailing and Consumer Services 20(5): 495-503

Iyer, P., Davari, A., and A. Mukherjee. 2018. Investigating the effectiveness of retailer's mobile applications in determining customer satisfaction and repatronage intentions? A congruency perspective. Journal of Retailing and Consumer Services 44(1): 235-243.

Izquierdo-Yusta, A., Olarte-Pascual, C., and E. Reinares-Lara. 2015: Attitudes toward mobile advertising among users versus non-users of the mobile Internet. Telematics and Informatics 32(2): 255-266.

Kang, J-Y., Mun, J., and K. Johnson. 2015. In-store mobile usage: Downloading and usage intention toward mobile location-based retail apps. Computers in Human Behavior, 46(1): 210-217.

Khajehzadeh, S., Oppewal, H., and D. Tojib. 2015. Mobile coupons: what to offer, to whom, and where? European Journal of Marketing 49(5): 851-873.

Kim, C., Li, W., and D. Kim. 2015. An Empirical Analysis of Factors Influencing M-Shopping Use. International Journal of Human-Computer Interaction 31(12): 974-994.

Kim, M., Kim, J., Choi, J., and M. Trivedi. 2017. Mobile Shopping Through Applications: Understanding Application Possession and Mobile Purchase. Journal of Interactive Marketing 39(1): 55-68. 
Kim, Y., and J. Han. 2014. Why smartphone advertising attracts customers: A model of Web advertising, flow and personalization. Computers in Human Behavior 33(1): 256-269.

Koo, W. 2016. Usage of Smartphone Applications: A Descriptive Study of Top 100 U.S. Retailers. International Journal of Interactive Mobile Technologies 10(3):. 54.-58.

Kowatsch, T., and W. Maas. 2010. In-store consumer behavior: How mobile recommendation agents influence usage intentions, product purchases and store preferences. Computers in Human Behavior 26(4): 697-704.

Kowatsch, T., Maas, W., and E. Fleisch. 2011. The role of product reviews on mobile devices for in-store purchases: consumers' usage intentions, costs and store preferences. International Journal of Internet Marketing and Advertising 6(3): 226-243.

Lai, J., Debberma, S., and K. Ulhas. 2012. An empirical study of consumer switching behavior towards mobile shopping: a Push-Pull-Mooring model. International Journal of Mobile Communications 10(4): 386-404.

Lazaris, C., and A. Vrechopoulos. 2014. From Multichannel to 'Omnichannel' Retailing: Review of the Literature and Calls for Research. $2^{\text {nd }}$ International Conference on Contemporary Marketing Issues Lee, H.-J. 2017. The Differential Factors Influencing Online and Mobile Shopping Behavior. Journal of Distribution Science 15(9): 27-36.

Lee, Y., and H.-Y. Kim. 2018. Consumer need for mobile app atmospherics and its relationships to shopper responses. Journal of Retailing and Consumer Services (in press)

Lemon, K., and P. Verhoef. 2016. Understanding customer experience throughout the customer journey. Journal of Marketing 80(6): 69-96.

Lin, H. 2012. The effect of multi-channel service quality on mobile customer loyalty in an online-andmobile retail context. The Service Industries Journal 32(11): 1865-1882.

Ltifi, M. 2018. Determinants of the intention of smartphone usage by mobile internet users for mservices. Management Decision 56(11): 2291-2307.

Mays, N., Pope, C., and J. Popay. 2005. Systematically reviewing qualitative and quantitative evidence to inform management and policy-making in the health field. Journal of Health Services Research \& Policy 10(1): 6-20.

McLean, G., Al-Nabhani, K., and A. Wilson. 2018. Developing a Mobile Applications Customer Experience Model (MACE) - Implications for Retailers. Journal of Business Research 85(1): 325-336.

Melis, K., Campo, K., Breugelmans, E., and L. Lamey. 2015. The Impact of the Multi-channel Retail Mix on Online Store Choice: Does Online Experience Matter? Journal of Retailing 91(2): 272-288.

Melumad, S., Inman, J., and M. Pham. 2015. The Distinct Psychology of Smartphone Use: SmartphoneGenerated Contenet as Emotional Expression. Advances in Consumer Research 43(1): 117-118.

Morosan, C., and F. Agnes. 2016. Modeling guests' intentions to use mobile apps in hotels: The roles of personalization, privacy and involvement. Journal of Contemporary Hospitality Management 28(9): 1961-1991.

Natarajan, T., Balasubramanian, S., and D. Kasilingam. 2017. Understanding the intention to use mobile shopping applications and its influence on price sensitivity. Journal of Retailing and Consumer Services 37(1): 8-11.

Oh, L., Teo, H., and V. Sambamurthy. 2012. The effects of retail channel integration through the use of information technologies on firm performance. Journal of Operations Management 30(5): 368-381. Ono, A., Nakamura, A., Okuno, A., and M. Sumikawa. 2016. Consumer Motivations in Browsing Online Stores with Mobile Devices. International Journal of Electronic Commerce 16(4): 152-177.

Palmatier, R., Houston, M., and J. Hulland. 2017. Review articles: purpose, process and structure. Journal of the Academic Marketing Science 46(1): 1-5. 
Pantano, E. 2014. Innovation drivers in retail industry. International Journal of Information Management 34(3): 344-350.

Pantano, E., and C.-V. Priporas. 2016. The effect of mobile retailing on consumers' purchasing experiences: A dynamic perspective. Computers in Human Behavior 61(1): 548-555

Pantano, E., and M. Viassone. 2015. Engaging consumers on new integrated multichannel retail settings: Challenges for retailers. Journal of Retailing and Consumer Services 25(1): 106-114

Pauwels, K, and S. Neslin. 2015. Building with Bricks and Mortar: The Revenue Impact of Opening Physical Stores in a Multichannel Environment. Journal of Retailing 91(2): 182-197.

Persaud, A., and I. Azhar. 2012. Innovative mobile marketing via smartphones: Are consumers ready? Marketing Intelligence \& Planning 30(4); 418-443.

Piotrowicz, W., and R. Cuthbertson. 2014. Introduction to the special issue information technology in retail. Toward omnichannel retailing. International Journal of Electronic Commerce 18(4): 5-16.

Pittaway, L., Robertson, M., Munir, K., Denyer, D., and A. Neely. 2004. Networking and innovation: A systematic review of the evidence. International Journal of Management Reviews 5-6 (3-4); 137-168. Pousttchi, K., and Y. Hufenbach. 2014. Engineering the Value Network of the Customer Interface and Marketing in the Data-Rich Retail Environment. International Journal of Electronic Commerce 18(4): 17-42.

Qubit, 2018. The growing influence of mobile discovery on ecommerce revenue. Available at: https://www.qubit.com/research/mobile-product-discovery-ecommerce-revenue/?utm_source=pressrelease\&utm_medium=press\%20release\&utm_campaign=2018-Q1-Mobile-Product-Discovery\# Rigby, D. 2011. The Future of Shopping. Harvard Business Review 89(12): 64-75. Rippé, C., Weisfeld-Spolter, S., Yurova, Y., Dubinsky, A., and D. Hale. 2017. Under the sway of a mobile device during an in-store shopping experience. Psychology \& Marketing 34(7): 733.-752. Riquelme, I., Román, S., and D. Iacobucci. 2016. Consumers' Perceptions of Online and Offline Retailer Deception: A Moderated Mediation Analysis. Journal of Interactive Marketing 35(1): 16-26.

Rosenblum, P., and S. Rowen. 2012. The 2012 retail store: In transition. Benchmark Report, Retail Systems Research, Miami, May 2012 (available at http://rsrresearch.com/wpcontent/uploads/2012/05/RSR_Store_Report_2012.pdf).

Sciandra, M., and J. Inman. 2015. Smart Phones, Bad Calls? In-Store Mobile Technology Use and Consumer Purchase Behavior. Advances in Mobile Consumer Behavior 43(1): 117-121.

San-Martin, S., Lopez-Catalan, B., and M. Ramon-Jeronimo. 2013. Mobile Shoppers: Types, Drivers, and Impediments. Journal of Organizational Computing and Electronic Commerce 23(4): 350-371. Shang, D., and W. Wu. 2017. Understanding mobile shopping consumers' continuance intention. Industrial Management \& Data Systems 117(1): 213-227.

Shankar, V., Venkatesh, A., Hofacker, C., and P. Naik. 2010. Mobile marketing in the retailing environment: current insights and future research avenues. Journal of Interactive Marketing 24(2): 1-28. Singh, S., and J. Swait. 2017. Channels for search and purchase: Does mobile Internet matter? Journal of Retailing and Consumer Services 39(6): 123-134.

Spaid, B., and D. Flint. 2014. The Meaning of Shopping Experiences augmented By Mobile Internet Devices. Journal of Marketing Theory and Practice 22(1): 73-90.

Ström, R., Vendel, M., and J. Bredican. 2014. Mobile marketing: A literature review on its value for consumers and retailers. Journal of Retailing and Consumer Services 21(6): 1001-1012.

Suki, N. 2011. A structural model of customer satisfaction and trust in vendors involved in mobile commerce. International Journal of Business Science and Applied Management 6(2): 17-30.

Tarute, A., Nikou, S., and R. Gautis. 2017. Mobile application driven consumer engagement. Telematics and Informatics 24(4): 145-156. 
Taylor, D., and M. Levin. 2014. Predicting mobile app usage for purchasing and information-sharing. International Journal of Retail \& Distribution Management 42(8): 759-774.

Thakur, R. 2016. Understanding customer engagement and loyalty: A case of mobile devices for shopping. Journal of Retailing and Consumer Services 32(5): 151-163.

Trivedi, J., and J. Trivedi. 2018. Investigating the Factors That Make a Fashion App Successful: The Moderating Role of Personalization. Journal of Internet Commerce 17(2): 170-187.

Varadarajan, R., Srinivasan, R., Vadakkepatt, G., Yadav, M., Pavlou, P., Krisnamurthy, S., and T. Krause. 2010. Interactive Technologies and Retailing Strategy: A Review, Conceptual Framework and Future Research Directions. Journal of Interactive Marketing 24(2): 96-110.

Verhoef, P., Kannan, P.K., and J. Inman. 2015. From Multi-Channel Retailing to Omni-Channel Retailing: Introduction tothe Special Issue on Multi-Channel Retailing. Journal of Retailing 91(2): 174181.

Verkijika, S. F. 2018. Factors influencing the adoption of mobile commerce applications in Cameroon. Telematics and Informatics (article in press)

Voropanova, E. 2015. Conceptualizing smart shopping with a smartphone: implications of the use of mobile devices for shopping productivity and value. The International Review of Retail, Distribution and Consumer Research 25(5): 529-550.

Wang, R., Malthouse, E., and L. Krisnamurthi. 2015. On the Go: How Mobile Shopping Affects Customer Purchase Behavior. Journal of Retailing 91(2): 217-234.

Wong, C., Tan, G., Ooi, K., and B. Lin. 2014. Mobile shopping: the next frontier of the shopping industry? An emerging market perspective. International Journal of Mobile Communications 13(1): 1050-1067.

Yang, S., Chen, Y., and J. Wei. 2015.Understanding consumer's web-mobile shopping extension behavior: a trust transfer perspective. The Journal of Computer Information Systems 55(2): 79-87. Yang, K. 2010. Determinants of US consumer mobile shopping services adoption: implications for designing mobile shopping services. Journal of Consumer Marketing 27(3): 262-270.

Yang, K. 2012. Consumer technology traits in determining mobile shopping adoption: An application of the extended theory of planned behavior. Journal of Retailing and Consumer Services 19(5): 484-491. Yang, K. and J. Forney. 2013. The Moderating Role of Consumer Technology Anxiety in Mobile Shopping Adoption: Differential Effects of Facilitating Conditions and Social Influences. Journal of Electronic Commerce Research 14(4): 334-347

Yang, K., and H.-Y. Kim. 2012. Mobile shopping motivation: an application of multiple discriminant analysis, International Journal of Retail \& Distribution Management 40(10): 778-789.

Zhang, R., Chen, J., and C. Lee. 2013. Mobile Commerce and Consumer Privacy Concerns. The Journal of Computer Information Systems 53(4): 31-38.

Zubcsek, P., Katona, Z., and M. Sarvary. 2015. Smart Phones, Bad Calls? In-store Mobile Technology Use and consumer Purchase Behavior. Advances in Consumer Research 43(1): 120.-121. 
Appendix: Quality Assessment Criteria for Review Articles, Pittaway et al. (2004)

\begin{tabular}{|c|c|c|c|c|c|c|}
\hline & & & & Level & & \\
\hline Element & & 0 Absence & 1 Low & 2 Medium & 3 High & $\begin{array}{l}\text { Not } \\
\text { applicable }\end{array}$ \\
\hline 1. & $\begin{array}{l}\text { Theory } \\
\text { robustness }\end{array}$ & $\begin{array}{l}\text { The article does } \\
\text { not provide } \\
\text { enough } \\
\text { information to } \\
\text { assess this } \\
\text { criterion }\end{array}$ & $\begin{array}{l}\text { Poor awareness } \\
\text { of existing } \\
\text { literature and } \\
\text { debates. Under- } \\
\text { or } \\
\text { overreferenced. } \\
\text { Low validity of } \\
\text { theory }\end{array}$ & $\begin{array}{l}\text { Basic } \\
\text { understanding of } \\
\text { the issues } \\
\text { around the topic } \\
\text { being discussed. } \\
\text { The theory is } \\
\text { weakly related } \\
\text { to data }\end{array}$ & $\begin{array}{l}\text { Deep and broad } \\
\text { knowledge of } \\
\text { relevant } \\
\text { literature and } \\
\text { theory relevant } \\
\text { for addressing } \\
\text { the research. } \\
\text { Good relations } \\
\text { theory-data }\end{array}$ & $\begin{array}{l}\text { This element is } \\
\text { not applicable } \\
\text { to the document } \\
\text { or study }\end{array}$ \\
\hline 2. & $\begin{array}{l}\text { Methodology, } \\
\text { data and } \\
\text { supporting } \\
\text { arguments }\end{array}$ & As above & $\begin{array}{l}\text { Data inaccuracy } \\
\text { and not related to } \\
\text { theory. Flawed } \\
\text { research design }\end{array}$ & $\begin{array}{l}\text { Data are related } \\
\text { to arguments, } \\
\text { though there are } \\
\text { some gaps. } \\
\text { Research design } \\
\text { may be } \\
\text { improved }\end{array}$ & $\begin{array}{l}\text { Data strongly } \\
\text { supports } \\
\text { arguments. } \\
\text { Besides, the } \\
\text { research design } \\
\text { is robust: } \\
\text { sampling, data } \\
\text { gathering, data } \\
\text { analysis is } \\
\text { rigorous }\end{array}$ & As above \\
\hline 3. & $\begin{array}{l}\text { Implication for } \\
\text { practice }\end{array}$ & As above & $\begin{array}{l}\text { Very difficult to } \\
\text { implement the } \\
\text { concepts and } \\
\text { ideas presented. } \\
\text { Not relevant for } \\
\text { practitioners or } \\
\text { professionals }\end{array}$ & $\begin{array}{l}\text { There is } \\
\text { potential for } \\
\text { implementing } \\
\text { the proposed } \\
\text { ideas, with } \\
\text { minor revisions } \\
\text { or adjustments }\end{array}$ & $\begin{array}{l}\text { Significant } \\
\text { benefit may be } \\
\text { obtained if the } \\
\text { ideas being } \\
\text { discussed are put } \\
\text { into practice }\end{array}$ & As above \\
\hline 4. & Generalizability & As above & $\begin{array}{l}\text { Only to the } \\
\text { population } \\
\text { studied }\end{array}$ & $\begin{array}{l}\text { Generalizable to } \\
\text { organizations of } \\
\text { similar } \\
\text { characteristics }\end{array}$ & $\begin{array}{l}\text { High level of } \\
\text { generalizability }\end{array}$ & As above \\
\hline 5. & Contribution & As above & $\begin{array}{l}\text { Does not make } \\
\text { an important } \\
\text { contribution. It is } \\
\text { not clear the } \\
\text { advances it } \\
\text { makes }\end{array}$ & $\begin{array}{l}\text { Although using } \\
\text { others' ideas, } \\
\text { builds upon the } \\
\text { existing theory }\end{array}$ & $\begin{array}{l}\text { Further develops } \\
\text { existing } \\
\text { knowledge, } \\
\text { expanding the } \\
\text { way the issue } \\
\text { was explained so } \\
\text { far }\end{array}$ & As above \\
\hline
\end{tabular}

